\title{
Experiences in Academic Literacy with MOOC
}

\author{
Dilmeire Sant'Anna Ramos Vosgerau', Patricia Meyer², Joanita do Rocio Artigas ${ }^{1}$, \\ Juslaine Lucília Mickosz Dallegrave ${ }^{3}$ \\ ${ }^{1}$ Post-Graduate Program in Education, Pontifical Catholic University of Paraná, Curitiba, Brazil \\ ${ }^{2}$ Collegiate Events and Audiovisual Production, Federal Institute of Paraná, Curitiba, Brazil \\ ${ }^{3}$ Educational Department, Dom Bosco High School, Curitiba, Brazil \\ Email: dilmeire.vosgerau@pucpr.br, patricia.meyer@ifpr.edu.br, joanitaartigas@gmail.com, \\ juslainelucilia@brturbo.com.br
}

Received 6 July 2016; accepted 15 August 2016; published 18 August 2016

Copyright (C) 2016 by authors and Scientific Research Publishing Inc.

This work is licensed under the Creative Commons Attribution International License (CC BY). http://creativecommons.org/licenses/by/4.0/

(c) (i) Open Access

\section{Abstract}

Academic literacy is defined as a student having developed the skills and competencies related to the appropriation of writing inserted in the social practices and with the possibility to build and rebuild concepts and meanings. There are various studies that focus on the difficulties of university students in relation to the mother tongue, which highlights the importance of proposing and evaluating new processes and strategies geared towards academic literacy. This study aims to analyze the possibilities and limit of the use of technology as a support to the mediation process, interaction and dialogicity within structured didactic proposals in a closed and open virtual learning environment (MOOC), aiming at academic literacy. The theoretical premises of Feuerstein, Feuerstein, \& Falik (2014) and Bakhtin (2010), especially in relation to the concepts of mediation, interactionism and dialogism, support two developed training proposals, tested and evaluated by teachers and graduate students, using the methodological referrals of research development (Van der Maren, 2003). In the first model, in a closed platform, a didactic sequence structured in a virtual learning environment was transposed. Only one of the activities (radioweb) was opened. It was observed that the lack of familiarity with the environment, as well as its formal organization and the lack of diversification of learning activities, can demotivate the student in the literacy process. This experience has given evidence of the importance of the use of resources that favor a more constant feedback to the student, allowing them to create their own pace of learning. Through the second model, which follows the assumptions of the construction of a MOOC, it can be inferred that the diversity in integrating technologies can offer conditions for self-learning, interaction and cooperation between pairs, with the goal of making the learning of the Portuguese language and academic genres more significant. 


\section{Keywords}

\section{Higher Education, Academic Literacy, Digital Technology}

\section{Introduction}

This study aims to analyze the possibilities and limits of the use of technology to support the processes of mediation, interaction and dialogicity, from the comparison of two proposals that aim at academic literacy, one in a closed virtual learning environment and another in an open environment (open and massive online course, or MOOC). The scenario for the development of the study is the Brazilian university, challenged and questioned in its traditional model and referred to here due to its essential role in the social, cultural and economical development of contemporary society. Democratization, expansion of access to undergraduate courses and the heterogeneity of the body of students entering universities are some of the factors cited by Zabalza (2004) that add complexity to this context and propel the university to a new level of quality in teaching and learning.

In relation to the quality of higher education, Cunha, Zanchet, \& Ribeiro (2013) affirm that the universities, at world level, are in the process of defining a design that meets the needs of the knowledge and social demands in the contexts in which they are inserted, generating a reassessment in relation to their teaching practices. Both Cunha, Zanchet, \& Ribeiro (2013), regarding Zabalza (2004), emphasize that the university must assume its role as an "organization", an "institution of learning" and "a living organism", to the extent that it establishes intense relations with the environment, and presents a robust internal dynamic, both of conflicts and of changes, in which the professionals of higher education, teachers and students, have an important role.

Recent innovations in the university space are closely related to the needs presented by students and to how they interact with the university. This is reflected both in the infrastructure as well as in methodological aspects, with reference, for example, to the ownership of technology by means of the proposals offered by blended learning. If it is left to the lecturers to potentiate the learning outcomes of the students, it is fundamental for an intense didactic effort to be made to match the organization of courses and teaching methods to the different learning styles (Zabalza, 2004).

There is often concern regarding the processes and strategies that make academic literacy possible. The mother tongue is an essential factor for national and cultural identity. Portuguese, being the official language, is used for teaching in schools and in spoken and written communication. The mastery of reading and writing is therefore essential for the social relationship of individuals, for the production of knowledge, and for professional exercise and citizenship.

Even after 12 years of schooling, the student arrives at the university presenting difficulties using their mother tongue. It is stipulated that, for a student to join a university, they should complete a selection process, be competent in reading and comprehension, and be able to speak and write in situations that require formality. However, evidence that university students have difficulty in understanding and writing texts has caused a change in the admission exams in these institutions: multiple-choice tests have been replaced by essays, and the weight of the essay has been increased (Brasil, 1997).

Araújo, Careno, Luna, \& Leal (2005), from the experience in the discipline of Reading and Production of Texts in two universities, noted that the students have an intuitive understanding of the language. However, when asked to write in the academic sphere and in a formal way, they have difficulty in transposing the informal oral modality to the formal written modality. It is also common for undergraduate freshmen to be unaware of the textual genres and to not have any previous experience with the academic genres. Abstracts, reviews, articles and essays are previously ignored and obscure elements.

The unpreparedness of university students in the efficient use of language, therefore, requires the development of strategies to overcome the problem, especially due to the fact that full mastery of the mother tongue is a prerequisite in any professional area, as well as for the exercise of criticality and citizenship. One of the possible alternatives is the integration of digital technology, an option that is strengthened to the extent that the students, in the era of digital culture, write continuously by means of messages on the internet, create virtual communities, use social networks and interact intensely with various people, without the school ordering them to (Elias, 2011). 
Although a significant portion of students are familiar with digital technology, this does not imply the full mastery of resources, or that they understand its educational applications. A dichotomy is therefore identified: young people write all the time, and yet they write poorly.

This difficulty sometimes extends over the periods or years of graduate courses and reaches its peak in the preparation of the concluding work of the course. That would be a challenge of production and systematization of knowledge, and an immersion in the precepts of research and scientific rigor also reveal the difficulties with the efficient formal use of our own language. Thus, for this study, it is proposed as a matter of research, to analyze the possibilities and limits of the use of technology as a support to the mediation, interaction and processes of dialogicity within didactic proposals structured in a closed virtual learning environment and in an open environment, MOOC, aiming at academic literacy.

\section{Mediation, Interactionism and Dialogicity Supported by Technology}

Writing is a conquest, an acquisition which requires determination, practice, learning and time. The pedagogical action, the selection of activities and the characteristics of the teaching work, also influence the context of academic literacy. It also interferes in the context of learning the conception of a language. There is a general consensus that language should be worked on through an interactionist perspective, in which the subject-author has the opportunity to interact with the other, to attempt to modify the other, and that the text does not work alone but acquires meaning and builds itself on the moment of reception, influenced by the historical and social context of the subject-reader (Bakhtin, 2010). However, other conceptions of language underly education: the conception of language as expression of thought, and language as an instrument of communication.

According to Travaglia (2000), Marcuschi (2003) and Koch (2002), in the interactionist conception of language, the subject performs actions, and acts with the interlocutor, language being a place of human interaction that occurs in the production of effects of sense between the interlocutors in a given situation of communication and in a socio-historical and ideological context. Without the other, there is no language, and, if there is any attempt to write, it will be empty, without sense, not going beyond the act of drafting of mechanical training, an exercise to organize signals (Antunes, 2003).

The interactionist conception of the teaching of language, defended by Antunes (2003), promotes a productive, functional and contextualized practice, from the interactive activity between two or more interlocutors in real situations and diversified in operation. His understanding is that the language is at the service of the communication. Thus, the standard to be used and taught should be guided in their own language uses, creating reflections and answers to the questions of writing, reading and orality, in situations that promote the interaction between people.

Writing is inserted in all social situations: work, family, school and social life, and therefore cannot be separated from the contexts in which it meets its communicative function. Producing a formal written text requires a protocol divided into stages that are inter-related, which require planning, writing, review and rewriting. Each of these steps has its characteristics that must be respected, because these stages determine the final condition of the text. When searching for academic literacy, it is important to highlight the need of the student and their demands to be the center of the strategy of learning and not the teacher. Therefore, the teacher becomes a mediator, a perspective which is reinforced by the interaction and ease of communication made possible by digital technology. It is interesting to mention, however, that this proximity engages an affective perspective in the learning process, which implies that the cognitive and affective dimensions are structural elements of the learning act (Feuerstein, Feuerstein, \& Falik, 2014).

Feuerstein, Feuerstein, \& Falik (2014) lay down the following as requirements for the mediation: intentionality, reciprocity, transcendence and meaning, criteria considered universal, to which others are added which are not considered less important, since they enrich the mediation as a process, such as the feeling of competence, self-regulation, sharing, individuation, psychological differentiation, planning, challenge, self-modification, optimism and a sense of belonging. However, these criteria should not be taken as laws, because they alternate with each other, they complement each other.

In mediation, intentionality and reciprocity are inseparable. The determination of the mediator in helping the mediated to understand the object of study composes the concept of intentionality. The mediator interacts with the mediated, in order to enable the seizure of content, while reciprocity is shared between mediator and mediated of the intention of the learning process, which cannot be incidental. The experience of mediated learning 
causes structural changes that help the mediated to respond to different demands in different contexts. This definition of transcendence presents the possibility of appropriation of the concepts and principles, which, generalized, promote a holistic vision of reality.

It can be observed that the social interaction and communication are inseparable from the action of teaching, which can be maximized through the use of digital technology, which allows mediation to be performed, even at a distance (Kenski, 2003).

The technology of information and communication has intensified the perception that interactivity is essential to the educational process. This prospect involves profound changes in relation to the traditional model of education, centered on teacher performance, in a rhythm of determined studies and in which the student is inert, merely a container of information. The focus potentiates the collaboration between teacher and student for a joint construction of learning, from the most diverse communication channels, substantially scaled across the internet. There is a dynamism that replaces the linearity, in the relation between transmitters and receivers, a bidirectional or multidirectional rhythm, a participatory communication, with emphasis on the propitiation of dialog. The logic of distribution, transmission and storage of content gradually becomes irrelevant in relation to logic of communication and interactivity (Silva, 2006). The contents are the point of departure and not of arrival in the process of knowledge construction. Therefore, the student, in this active vision, creates, modifies and builds and, is the author of his or her own learning. The expectation is for the student to become more aware of their progress and difficulties, identifying what is needed to improve their performance, which is closely related to the vision of autonomy proposed by Eneau (2008) and Eneau and Develotte (2012), in which the comprehension of the subject as it is learned is an essential part of the process of empowerment. The teacher is the agitator, able to establish dynamic dialogs through online communication. For this, various resources can be offered with the potential to establish dialog and a pedagogical mediation, weakening the physical distance between the interlocutors and creating between them a scenario of collaboration and equality.

Distance Learning proposals imply alternative settings, both in relation to the different forms of establishing online communication and the fact that they may be in real time or not. In addition to the self-knowledge, online learning requires more time, discipline, dedication and organization. Eneau (2008) and Eneau and Develotte (2012) also put forward that autonomy does not entail learning alone, in a self-sufficient or isolated way. On the contrary, it emphasizes how the interpersonal relationship and the reciprocity, even in online learning experiences, are fundamental for the construction of the learner itself and autonomy. Autonomy assumes, therefore, a perspective of training, from the educational process, of a critical subject and citizen, much more than from an effective student or a successful professional. For this reason, being autonomous does not mean being self-sufficient but instead, an individual able to learn from others, learning from their actions, applying knowledge in different contexts and scenarios and understanding the process by which one learns, highlighting the reflective and social perspective and a process of construction of autonomy. The education of adults, with this, permeates a dimension of negotiation and dialog that is essential.

This interactive and dialogical practice does not imply a dependence on the computer, the Internet or other technological resource. They are not the owners or producers of knowledge. However, with the support of technology, it is possible to rearrange the way how learning is promoted. On the basis of their ownership, it is feasible to improve the transposition process of teaching, so that these resources can potentiate intelligence and learning. After all, technology itself is not sufficient to lead to the rupture of the traditional educational process. It is necessary to redesign the educational process, plan in what sense integration of technology leverages and serves learning, as well as to the spread and development of science (Gomez, 1992).

Online education, considered an educational modality in which the different possibilities of digital technologies are integrated, such as internet interfaces and tools of virtual environments of learning (chat, forums, e-mail, radioweb, among others), and, in this perspective, it converges different media and languages (Palloff \& Pratt, 2004), generating an arrangement that not only performs interconnections, but also the mediation of teaching and learning processes (Santos \& Riccio, 2011), not only in a perspective of distance but also face-to-face-the idea of blended learning or hybrid education.

In sum, for Santos and Riccio (2011), online education has a strong communicational and pedagogical potential, based on principles such as autonomy and interactivity. However, for such potential to be highlighted, it is necessary to plan the strategies of technological mediation, the didactic interactive design, didactic resources and the mediation of teaching. By interactive didactic design, the authors refer to the organization of content and learning situations that constitute the space of the online classroom, including the different devices that support 
the production, sharing and dissemination of content in different languages and formats (video, audio, images) or synchronous or asynchronous interaction (Paiva, 2012), between the interlocutors, such as chats, e-mail, forums, discussion lists, blogs, wikis, etc.

\section{Methodological Pathway}

The methodology, technique and instruments applied in both surveys follow the assumptions of the research development (Van der Maren, 2003). This methodology is used when developing a concept or instrument (object) — such as courses - or for drawing up proposals for the development of personal or professional skills. In the development of an object that is the aim of this research, they aim to solve a particular problem coming from daily practice. For both, five steps are pointed out: analysis of context, analysis of object, preparation, development, and deployment, according to Figure 1.

In Table 1, the steps and actions carried out in each of the surveys are described.

In the analysis of the context, the demands, as well as the target audience, the motivations, the intentions, the context, the contents, the means and procedures in which the problem occurs are observed. The first study conducted an interview, while the second undertook an examination of the final assignments and a questionnaire,

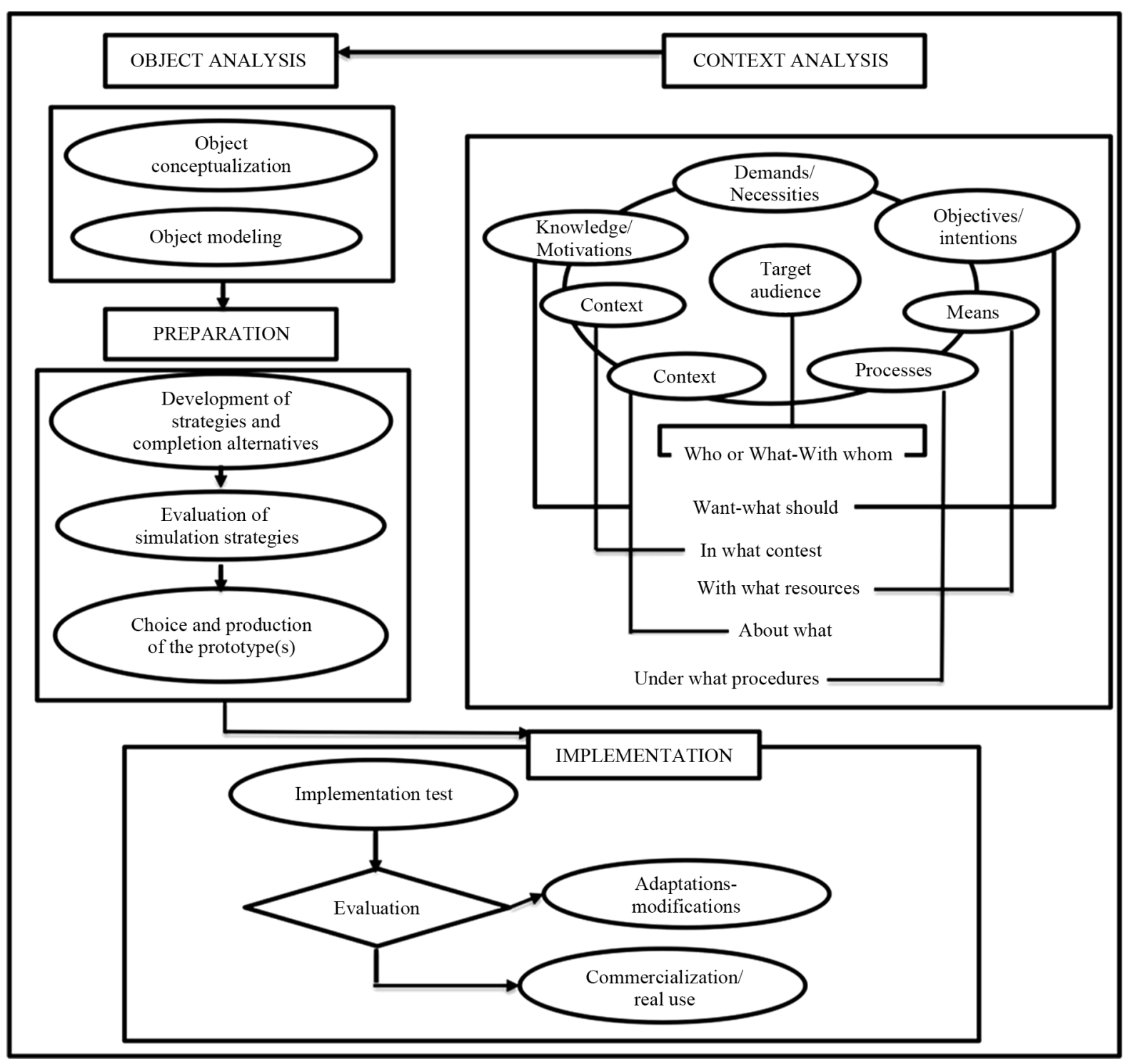

Figure 1. Steps of the research development (Van der Maren, 2003). 
Table 1. Stages of the research development.

\begin{tabular}{|c|c|c|}
\hline \multirow{2}{*}{ Stage } & \multicolumn{2}{|r|}{ Type of Environment } \\
\hline & Closed Course Environment & MOOC \\
\hline $\begin{array}{c}\text { The analysis of } \\
\text { the Context }\end{array}$ & $\begin{array}{l}\text { Interview with the teacher responsible for the } \\
\text { face-to-face course of academic literacy offered } \\
\text { by the university to students of all the } \\
\text { undergraduate courses. }\end{array}$ & $\begin{array}{l}\text { - Analysis of } 60 \text { final assignments. } \\
\text { online questionnaire sent to a thousand teachers of the institution } \\
\text { of higher education for the survey of structural, normative and } \\
\text { linguistic problems identified in the work-61 returned. }\end{array}$ \\
\hline $\begin{array}{c}\text { Analysis of } \\
\text { object }\end{array}$ & $\begin{array}{l}\text { Elaboration of the theoretical model of the } \\
\text { object based on the assumptions of Feuerstein } \\
\text { (2014) and some elements of Bakhtin (2010). }\end{array}$ & $\begin{array}{l}\text { Elaboration of the theoretical model of the object, considering } \\
\text { the research performed in a closed environment (de Dallegrave \& } \\
\text { Vosgerau, 2014) and further development in Bakhtin (2010). }\end{array}$ \\
\hline Preparation & $\begin{array}{l}\text { Analysis and selection of media and technology } \\
\text { available in the institutional virtual learning } \\
\text { environment. }\end{array}$ & $\begin{array}{l}\text { - Analysis of the limits on the use of the resources of the virtual } \\
\text { institutional learning environment identified by de Dallegrave \& } \\
\text { Vosgerau (2014). } \\
\text { - identification of technology for design of MOOCs, from } \\
\text { systematic review, which could help to overcome the limits } \\
\text { found in the research by de Dallegrave \& Vosgerau (2014). }\end{array}$ \\
\hline Development & $\begin{array}{l}\text { - Creation of the online course: "leveling of } \\
\text { Portuguese Language: production, writing, } \\
\text { genre summary", in the virtual institutional } \\
\text { learning environment. } \\
\text { - Validation through the implementation of the } \\
\text { course for graduate students, participants in } \\
\text { projects of scientific initiation. }\end{array}$ & $\begin{array}{l}\text { - Creation of MOOC: "Simplifying the TCC", on Moodle platform. } \\
\text { - Validation through the provision of access to } 36 \text { students who } \\
\text { have allowed the analysis of their final assignments ( } 36 \text { students } \\
\text { used the environment and responded to the validation } \\
\text { questionnaire). } \\
\text { - Validation through the provision of access to } 61 \text { teachers who } \\
\text { replied to the questionnaire (initial } 16 \text { teachers used the } \\
\text { environment and responded to the validation questionnaire). }\end{array}$ \\
\hline
\end{tabular}

available to a thousand teachers through the Qualtrics platform. The analysis of the data collected in the stage was performed using the technique of content analysis (Bardin, 2010) and using the Atlas.ti software.

The analysis of the object is composed of conceptualization and modeling, i.e. the analysis of a concept that is to be operated, from which, a model or prototype that is a coherent representation is prepared, responding to the needs identified in the analysis of the context. Once the representation has been established, strategies are elaborated, knowing that the final product will be a compromise between what is desired and what is possible, as Van der Maren (2003) explains. The difficulties cited in the context analysis stage were essential to the determination of demands to be met by the product. Based on Feuerstein, Feuerstein, \& Falik (2014), who lead the argument that learning is derived from the mediation, and Bakhtin (2010), who defends the establishment of the text through reading in a dialogical perspective, we opted to substantiate the proposals in the aspects of dialogism and mediation, making use of digital technology, and thus propose two models for the object of online learning.

In the preparation stage, the preparation and evaluation of strategies takes place. One of the actions carried out was the weighing of resources available in the virtual learning environments used for the two models of the course. Among the alternatives available in the virtual learning environment used in the closed course, the following resources were made available: work plan, e-mail, forum, video presentation of the contents and radioweb. For the MOOC, available openly in the Moodle environment, the following features were used: forum, chat, e-mail, blog, video presentation of the content, illustrative video content, comics and wiki. From the characteristics of each analyzed resource, it became possible to produce two models of pedagogical object.

In the development, the implementation test is conducted and, from this, an evaluation. On the basis of that evaluation, adaptations and necessary changes are made so that the prototype is then implemented. This process should be repeated as many times as necessary to reach an object model that meets the demands. Using this methodology, the online courses "Leveling of the Portuguese Language: production, writing, genre summary” and the MOOC "Simplifying the TCC” were developed on the Moodle platform.

\section{Description of the Implemented Courses}

The first online course, called "Leveling of the Portuguese Language: production, writing, genre summary”, was developed using existing resources in the virtual environment available at the university. This template applies 
digital resources and Web 1.0.

To take part in the course, in the development phase, 15 spots were available, without determining a specific year of admission to the university or prerequisites as to the field of use of the formal language. Experience in the use of the virtual environment was also not required, since the public was internal, i.e., students regularly enrolled in the university, and the use of the environment by the teachers is institutionalized since the year 2004. However, the course was first offered to students participating in the Scientific Initiation Program (PIBIC). Extra vacancies were open due to the demand for the course and a new class of 15 students was formed, totaling 30 enrolled students, in two separate classes. The course was organized from a didactic sequence (Schneuwly \& Dolz, 2011) adapted to the type of plan for the course of the virtual learning environment used, in eight stages, as demonstrated in Figure 2.

As shown in Figure 2, the different resources available on the platform were applied sequentially and planned to strengthen the proposed activities, enabling an itinerary of learning, an individualized care for students, seeing as the virtual learning environment allows the teacher to focus on specific difficulties.

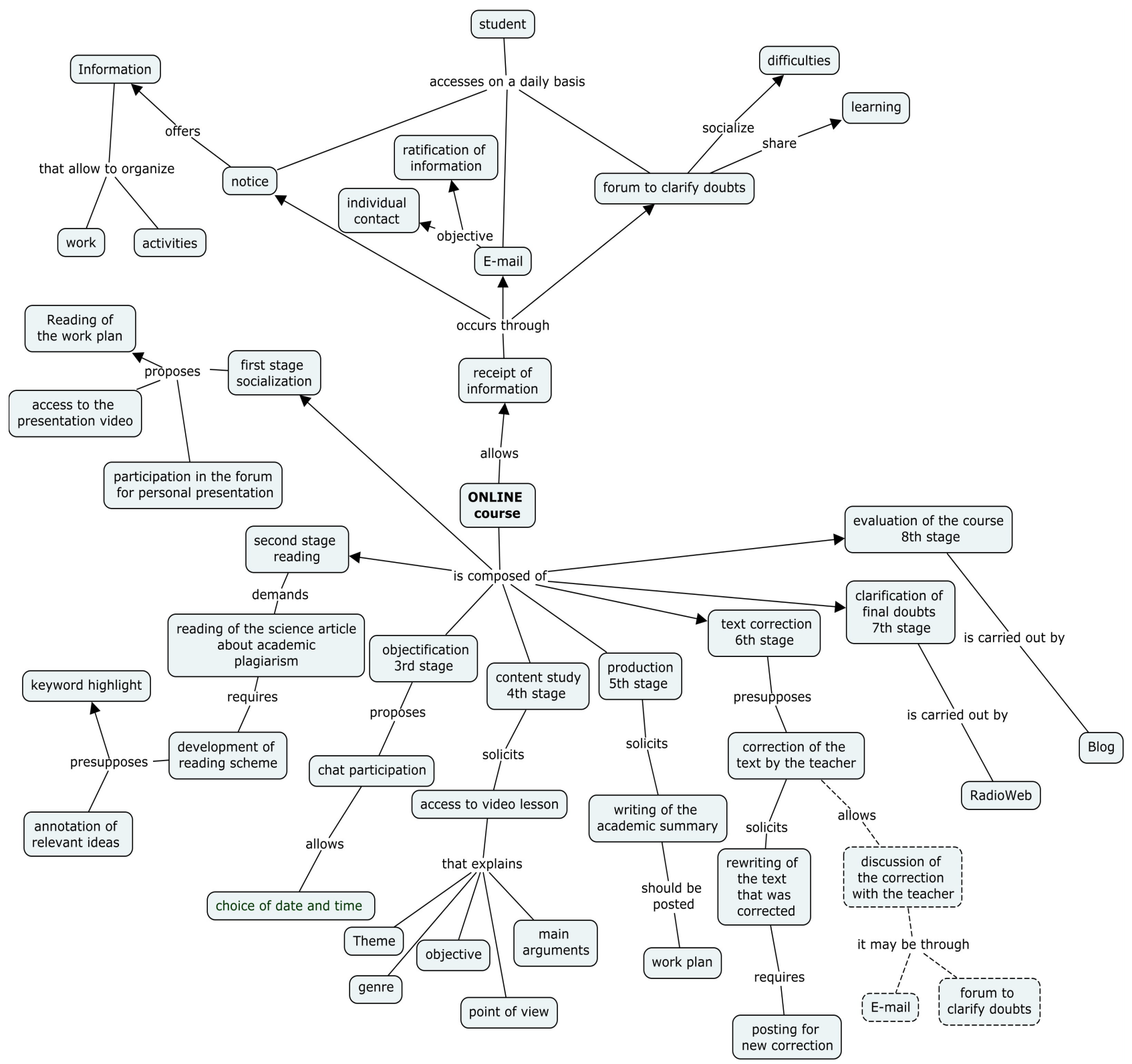

Figure 2. Activities proposed in the online course in a closed virtual institutional environment. 
To assist the students in their organization in relation to the course, the "Edital" tool was used on a daily basis, inserting messages that could guide and motivate the execution of the activities. The selection of the theme "academic summary" was the first required genre in the university. The initial phase of the course consisted of a host and presentation of the work plan to students, through the use of video, availability of the work plan and forum presentation of participants. The following proposition was the reading of a base-text and its exploration through the use of a reading guide. Subsequently, the participation in a chat was introduced, offered at two different times, to clarify doubts and to generate debate with regard to the theme of the text. From the understanding of the text and the discussion of the theme, the fourth step was the instrumentalization of the student in relation to the academic genre summary, through video classes. The finalization of this step consisted of an invitation for the student to produce and make a first textual production available, so that the doubts could be clarified by means of interaction via a forum. The interventions of the teacher in the text were performed with annotations in the margins, in a strategy of interactive revision, as defended by Nicola (2011). The problems encountered in the text were only identified but not corrected; this is because the need for reflection on the language takes the student to understand its operation and, consequently, to a better understanding (Antunes, 2003). The intention was that this step was repeated until the text was aligned to what is expected in the academic sphere and the assumptions of Feuerstein, Feuerstein and Falik (2014) regarding the mediation and meeting of the specific needs of the individual. The radioweb was available in the last stage, to make it possible to assess the progress in relation to the content, resources applied and activities, in accordance with the proposition of Van der Maren (2003), which aims to test the object of learning so that adjustments and adaptations may be made.

The second proposition of intervention, the MOOC "Simplifying the TCC", on the Moodle platform, consisted of a review of the previous models and used digital features which are characteristic of web 2.0. The proposals for activities of this course were organized as didactic and methodological in hypermedia mode, allowing students to interact with the content, giving them autonomy in choosing the sequence to study and conditions for a collaborative relation with their colleagues, allowing for discussion of the themes, and for formulating and reformulating concepts.

The participants in the course were composed of students of the class of the seventh period degree course in Pedagogy, from the same institution of education, and teachers who responded to the survey. Invitations were sent by e-mail and the enrollments were made on the website and released by the monitor of the course, for those who were interested in the certification. 36 students were enrolled in the course, for a total of one hundred vacancies released.

The educational modality MOOC is a recent online course and has a differentiated dynamic in its planning and implementation. There is a strong prospect of self-learning, in which the students need to organize their own personal activities so that they may learn with the Group of participants in the course and develop a structure of learning. The function of the advisor or instructor in MOOCs may be present or not. This role may be performed by a system of artificial intelligence. In addition to traditional didactic materials, such as videos, readings and sets of problems, the MOOC provides interactive user forums that help to build a community for students and teachers.

The course itself had as an objective to enable the participant to rewrite his final assignment with greater cohesion and coherence, prioritizing the organization of ideas and observation of the orthographic regularities, of accentuation and scoring, also considering the characteristics of the textual genre in question. It is observed in Figure 3, that there was a customization of the Moodle environment so that the student, when accessing the site, would feel that he was part of the course. Through this openness, an invitation was made to read a story in comic form, with the purpose of demonstrating that it is possible to learn how to learn better.

Figure 4 represents the options of the course that are available in the opening screen (Figure 3), below the link for the comic. The student could click directly on the option which gives access to the course and have access to all the study material and proposed activities, participate in the open forums where activities can be corrected by colleagues or a request can be made to have their activities corrected and evaluated by the teacher. In this case, the student, on completing all the activities successfully, would receive a certificate.

After the initial motivation and reflection derived from a comic book (reading activity), the course is organized in two modules and nine topics. The module "Simplifying the TCC", which gave its name to the course, was the main one and had "linguistic and grammar aspects in writing the TCC" as complementary. The main module was organized into the following topics: 1) "Plagiarism: what is it and how to avoid it", with the application of resources such as video, text, hyperlink and a questionnaire to verify learning; 2) "Paraphrase: what it 

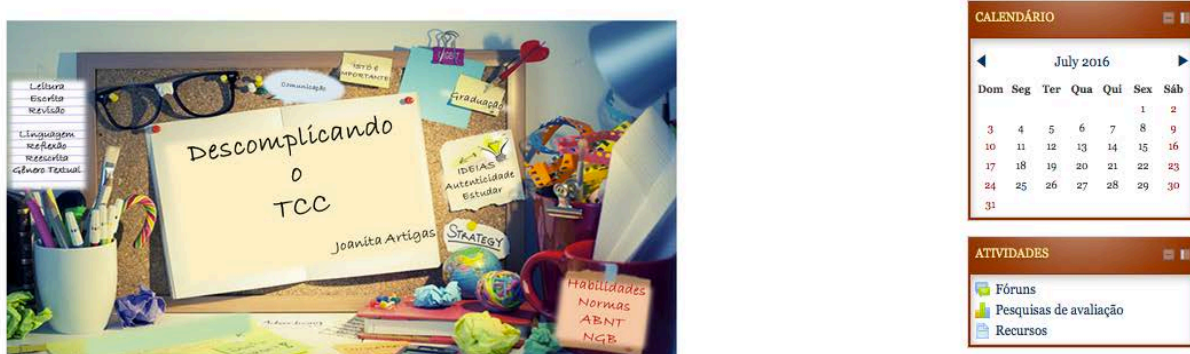

Clique na imagem para LER uma HQ, que irá mostrar como é possível "aprender" a "aprender" melhor...

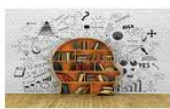

I. SOBRE ESTE CURSO

(1) A PROFESSORA

E Chamada virtual.

Figure 3. Opening screen that indicates "Click on the image to READ an "HQ" which shows how it is possible to "learn" and "learn" better".

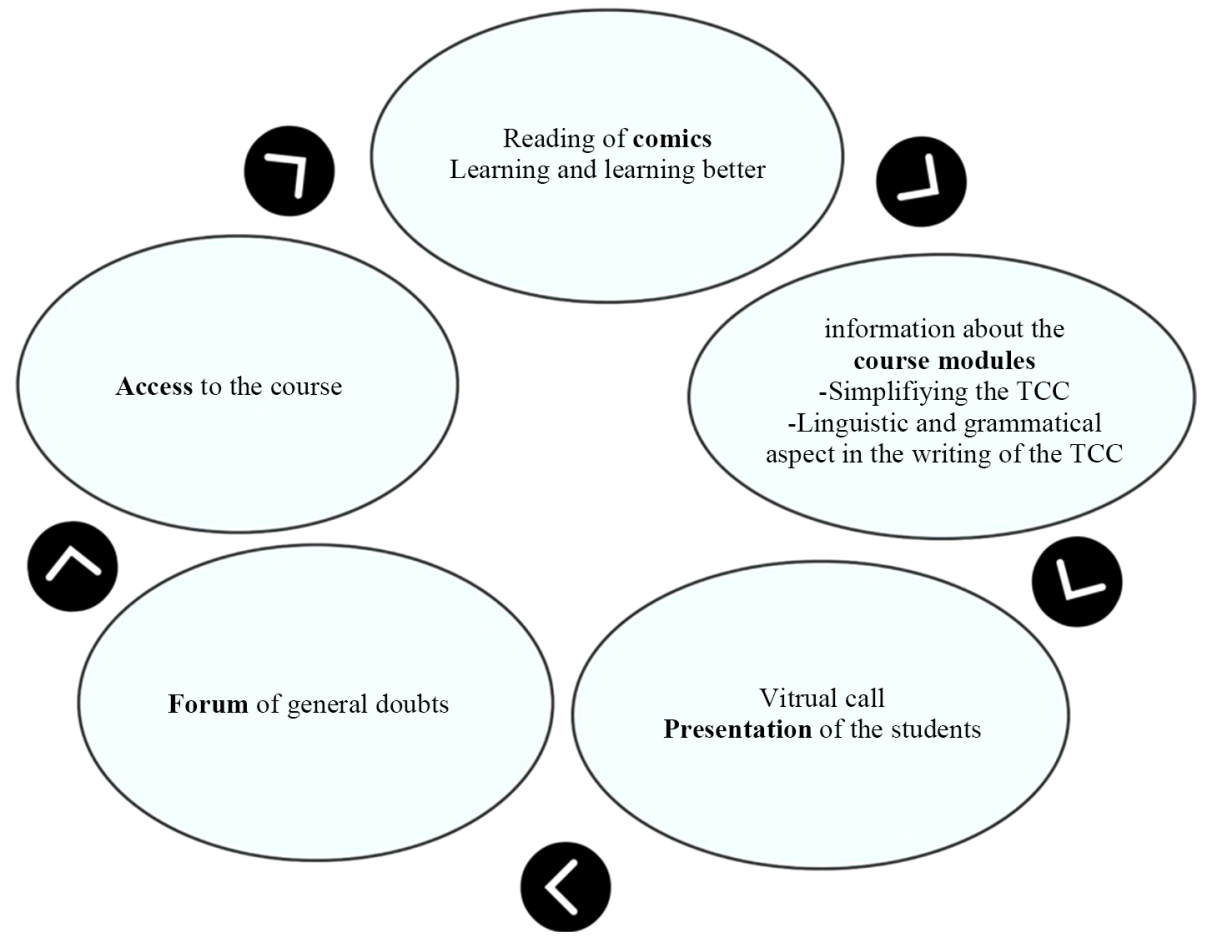

Figure 4. Presentation options of the course.

is and how to do it”, with a video lesson, used for presentation of the content, text and a forum with activities; 3) "How to elaborate the TCC I", addressing the delimitation of the research theme, with video lessons, presentation and text; 4) "How to develop the TCC II", on how to conduct academic research, with a video lesson; 5) "How to develop the TCC III", concerning the steps to be taken to complete the final assignment, with video lesson and diagrams/images; 6) "How to develop the TCC: final review", with video lesson and presentation; 7) 
"Considerations on presentation to the jury"; 8) "characteristics of the scientific text", with text, video and an activity using the wiki; 9) "Ethics on research", with text and video. The interaction during the course was made possible through chat and e-mail. The didactic design of the course is shown in Figure 5. It is important to emphasize that all the subjects have an activity of self-assessment of content and of the learning process.

In Table 2, the resources that were chosen to compose the two courses are described. In the online course available in the institutional environment, the resources were restricted to the possibilities offered by the environment itself and needed to meet the mediation principles (Feuerstein, Feuerstein \& Falik, 2014) and interaction (Bakhtin, 2010). For the design of the MOOC, resources from previous experiences were chosen (closed course) and the systematic review performed on the tools that could compose a MOOC and would meet the flexibility principle, as well as the principle of dialogicity (Bakhtin, 2010).

\section{Results}

\subsection{Difficulties with Regard to the Ownership of the Language}

In the proposal of the closed course, in the interview conducted with the teacher, before the development of the course, it was shown that there is a gap in knowledge of students who are new to the university with regard to the academic textual genres and a lack of techniques for technical and careful reading. Careful reading is understood as that which makes it possible to classify and select information of argumentative-expository text, which is essential for research and learning. Without careful reading, it becomes difficult to produce summaries, abstracts and other genres of the academic sphere.

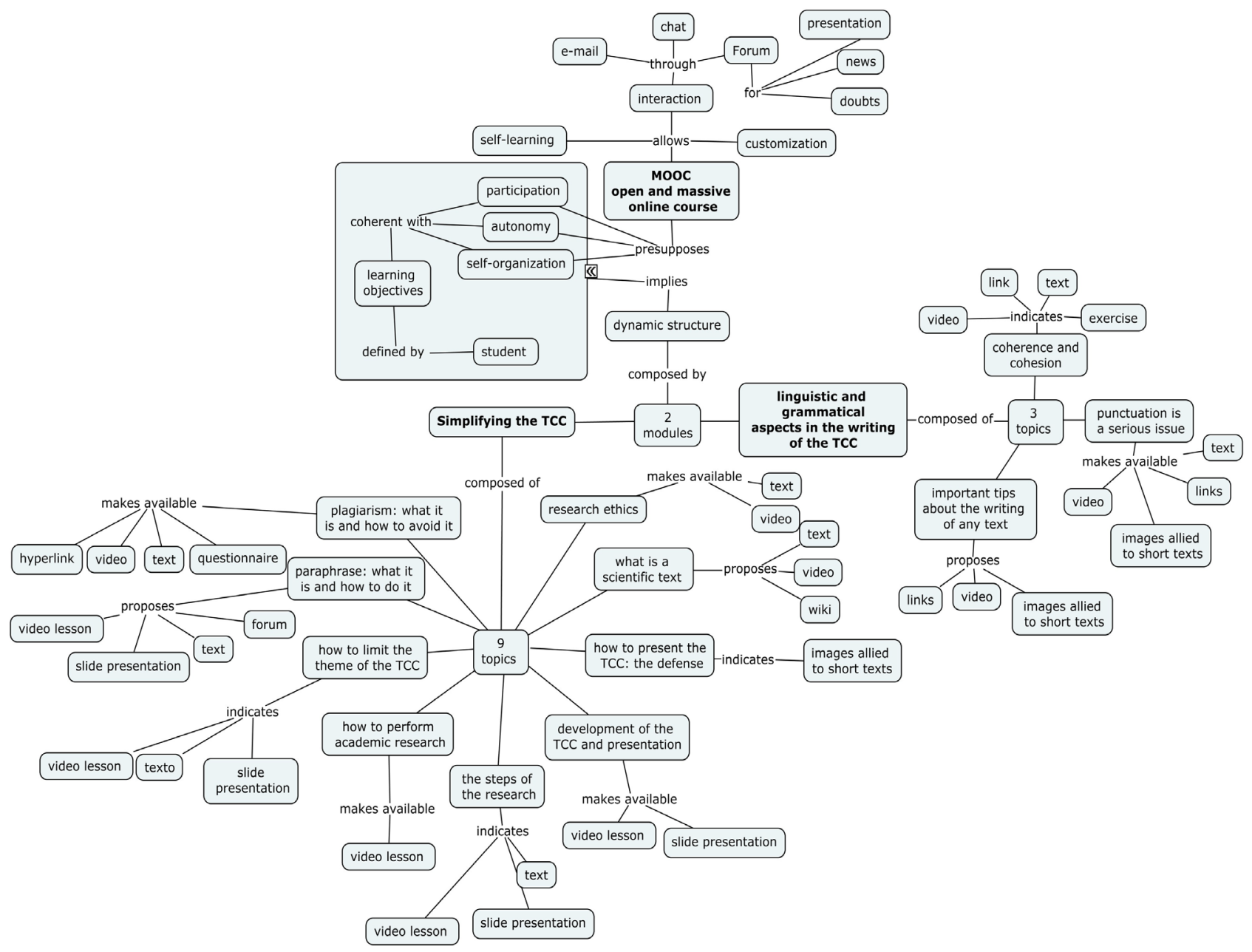

Figure 5. Drawing didactic proposed in MOOC. 
Table 2. Analysis of the resources chosen to compose the two courses.

\begin{tabular}{|c|c|c|c|c|}
\hline \multirow[b]{2}{*}{ Resource } & \multicolumn{2}{|c|}{ Course } & \multirow[b]{2}{*}{ Characteristics of Application } & \multirow{2}{*}{$\begin{array}{l}\text { The predominan } \\
\text { Principles }\end{array}$} \\
\hline & $\begin{array}{c}\text { Closed } \\
\text { Environment }\end{array}$ & MOOC & & \\
\hline Forum & Yes & Yes & $\begin{array}{l}\text { Asynchronous mediation resource, performed by means } \\
\text { of a framework of messages which can clarify doubts, } \\
\text { emit opinions, argue opinions issued by other users } \\
\text { (interaction) and exchange information. }\end{array}$ & $\begin{array}{l}\text { Interaction } \\
\text { Dialogism } \\
\text { Polyphony }\end{array}$ \\
\hline Chat & Yes & Yes & $\begin{array}{c}\text { Synchronous mediation resource to, which caters in a } \\
\text { satisfactory manner for the dynamics } \\
\text { of discussion of text. }\end{array}$ & $\begin{array}{l}\text { Interaction } \\
\text { Polyphony } \\
\text { Dialogism }\end{array}$ \\
\hline Blog & Not & Yes & $\begin{array}{l}\text { Related to remixing content, i.e. the production of content } \\
\text { from the propositions given. Used for example for } \\
\text { evaluation of the activities undertaken in the courses. }\end{array}$ & $\begin{array}{l}\text { Interaction } \\
\text { Dialogism } \\
\text { Polyphony }\end{array}$ \\
\hline Radioweb & Yes & No & $\begin{array}{l}\text { Allows for a more audible form of synchronous mediation, } \\
\text { and a more planned experience of orality which requires } \\
\text { greater care in design, making it an unparalleled activity } \\
\text { with regard to the experience of the production } \\
\text { of the oral text in a formal way. }\end{array}$ & $\begin{array}{l}\text { Interaction } \\
\text { Dialogism } \\
\text { Polyphony }\end{array}$ \\
\hline E-mail & Yes & No & $\begin{array}{l}\text { Asynchronous feature that allows the exchange of } \\
\text { messages, privately if necessary, which can be } \\
\text { directed to one or more users. }\end{array}$ & $\begin{array}{l}\text { Interaction } \\
\text { Dialogism }\end{array}$ \\
\hline $\begin{array}{l}\text { Video lesson for } \\
\text { the presentation } \\
\text { of the course }\end{array}$ & Yes & Yes & $\begin{array}{l}\text { Can motivate the student to initiate the } \\
\text { activities planned in the course. }\end{array}$ & Flexibility \\
\hline $\begin{array}{l}\text { Video lesson } \\
\text { presentation } \\
\text { of content }\end{array}$ & Not & Yes & $\begin{array}{l}\text { Allows mediation of content, asynchronously, acting } \\
\text { with sensory auditory and visual stimuli. Extends the } \\
\text { possibility of learning, because the content can be } \\
\text { reviewed as many times as necessary. }\end{array}$ & $\begin{array}{l}\text { Interaction } \\
\text { Flexibility }\end{array}$ \\
\hline $\begin{array}{l}\text { The learning } \\
\text { objects for } \\
\text { presentation } \\
\text { of content }^{\mathrm{c}}\end{array}$ & Not & Yes & $\begin{array}{l}\text { Allows mediation of content, asynchronously, acting with } \\
\text { sensory auditory and visual stimuli, as well as music and } \\
\text { writing. Extends the possibility of learning, because the } \\
\text { content can be reviewed as many times as necessary. }\end{array}$ & Flexibility \\
\hline Wiki & No & Yes & $\begin{array}{l}\text { Collaborative learning tool in which the students can work } \\
\text { in groups, contributing, commenting and editing content. } \\
\text { In the production context, it is possible to interfere, } \\
\text { interact and make changes to the statements. }\end{array}$ & $\begin{array}{l}\text { Interaction } \\
\text { Dialogism } \\
\text { Polyphony } \\
\text { Mediation }\end{array}$ \\
\hline
\end{tabular}

Notes: The image of the teacher is the center of recording and the message has as its purpose to provoke curiosity and interest in the students for the content. ${ }^{\mathrm{B}}$ THE CENTER OF RECORDING consists of the presentation of slides of the content, narrated by the teacher and alternated or not with the image of the teacher. ${ }^{\mathrm{C}}$ These are recordings of animated content, using Video Scribe software.

The aspects noted by the teacher are shown in Table 3, which compares the data collected from the interview with two other instruments proposed to determine the context for the production of the MOOC, also aiming to identify the difficulties of the students: questionnaire and analysis of final assignments.

\subsection{The Potential and Limits of the Use of Digital Technology in the Process of Academic Literacy}

From the development and implementation of the two strategies for online courses, it is possible, taking analysis of the obtained results into account, to point out potential and limits of the propositions in a comparative form. In the first column, Table 4 presents the limits shown in the online course "Leveling of Portuguese Language: production, writing, genre summary" and, in the second column, the actions performed and/or tools used in MOOC "Simplifying the TCC" to try to overcome these limitations.

The first limiting factor in closed environment online course was the withdrawal of students enrolled before the beginning of the course. The same problem was presented in relation to MOOC, however, because it is an 
Table 3. The difficulties of the students identified prior to the two courses.

\begin{tabular}{|c|c|c|c|}
\hline \multirow[b]{2}{*}{ Theme } & \multicolumn{3}{|c|}{ Course (Source) } \\
\hline & $\begin{array}{l}\text { Closed Environment } \\
\text { (Interview/teacher) }\end{array}$ & $\begin{array}{c}\text { MOOC } \\
\text { (Questionnaire/teachers) }\end{array}$ & $\begin{array}{c}\text { MOOC } \\
\text { (TCC/Students) }\end{array}$ \\
\hline $\begin{array}{l}\text { Textual } \\
\text { Genre }\end{array}$ & $\begin{array}{l}\text { The academic genres (academic } \\
\text { summary, review, article, testing etc.), } \\
\text { in general, constitute a challenge for the } \\
\text { good performance of textual production } \\
\text { and are considered the main problem. }\end{array}$ & $\begin{array}{l}\text { Lack of knowledge of } \\
\text { what is an academic genre. }\end{array}$ & $\begin{array}{l}\text { Ignorance in relation to genre for the } \\
\text { final assignment, including use of } \\
\text { inadequate linguistic variants. }\end{array}$ \\
\hline $\begin{array}{l}\text { Selection of } \\
\text { Information }\end{array}$ & $\begin{array}{l}\text { The students often do not have skills } \\
\text { such as selecting information in the text, } \\
\text { associating this information and to } \\
\text { classifying it as theme, issue, thesis } \\
\text { and arguments or counter-arguments. }\end{array}$ & & \\
\hline $\begin{array}{c}\text { Lack of } \\
\text { vocabulary }\end{array}$ & & $\begin{array}{l}\text { Lack of reading, which is evident in } \\
\text { the absence of appropriate vocabulary. } \\
\text { The students do not know how to justify } \\
\text { their affirmations based on references } \\
\text { and use common sense. } \\
\text { The students present recurrent orality } \\
\text { marks in the written text and difficulty } \\
\text { with expression in the written text. }\end{array}$ & \\
\hline $\begin{array}{l}\text { Aspects of } \\
\text { spelling and } \\
\text { accentuation }\end{array}$ & $\begin{array}{l}\text { The students almost do not present } \\
\text { problems related to surface issues of } \\
\text { the text, such as spelling and accent. }\end{array}$ & $\begin{array}{l}\text { Spelling aspects: incorrect writing, } \\
\text { segmentation and junction in } \\
\text { inappropriate words and errors } \\
\text { with accentuation. }\end{array}$ & $\begin{array}{l}\text { In relation to the spelling aspects, the } \\
\text { documents analyzed present an index of } \\
10.29 \% \text { of score, } 17.71 \% \text { of spelling and } \\
13.71 \% \text { accent. There were problems } \\
\text { with spelling and, with regards to } \\
\text { the use of the score conventions, } \\
\text { the students demonstrate that this } \\
\text { standardization of written language } \\
\text { was not assimilated, as in most of the } \\
\text { texts the score was used improperly. }\end{array}$ \\
\hline $\begin{array}{c}\text { Textual } \\
\text { Organization }\end{array}$ & $\begin{array}{l}\text { Deeper issues, such as the organization } \\
\text { of periods, cohesion and score, for } \\
\text { example, may appear more frequently } \\
\text { in the production of these students. }\end{array}$ & $\begin{array}{l}\text { The students do not have the } \\
\text { understanding that the meaning of a } \\
\text { part of the text does not stand alone, } \\
\text { but depends on other parties, } \\
\text { to which it is related. } \\
\text { The use of different people in } \\
\text { the speech. }\end{array}$ & $\begin{array}{l}\text { Lack of coherence, seeing as ideas } \\
\text { are not complete, causing a "break" } \\
\text { in the line of reasoning. Most of the } \\
\text { studies analyzed presented a deficiency } \\
\text { with regards to textual cohesion. } \\
\text { It is evident that this occurs because } \\
\text { there is no use of connectors and/or } \\
\text { appropriate prepositions to assist in } \\
\text { the understanding of the text. } \\
\text { The social conventions of writing } \\
\text { were not followed in relation to } \\
\text { verbal cohesion and nominal and } \\
\text { verbal combination. }\end{array}$ \\
\hline
\end{tabular}

open environment, and the student, even after having withdrawn from the course, continued to have access to material and could access it when he desired.

The first course was offered at the end of the school year and started at the beginning of the following year. It is possible that the existence of a Portuguese proficiency test on enrollment for the course positively influenced the interest in the course, which was compromised in passing the test. In relation to the MOOC, participants claimed that it was important that the course was available from the beginning of the school year and not only at the final stage of preparation and delivery of the final assignment, which may have caused disinterest in access to the course.

Despite being graduate students who were participating in a scientific initiation program, they demonstrated the difficulties of dealing with resources of the virtual institutional learning environment, showing that the instrumental difficulty can still be a limiting factor for the propositions related to the integration of technology in 
Table 4. The limits and potential found in course with a closed environment and changes for the production of MOOC.

\begin{tabular}{|c|c|c|}
\hline \multirow{2}{*}{ Element } & \multicolumn{2}{|c|}{ Type of Environment } \\
\hline & Course Closed Environment & MOOC \\
\hline Withdrawal & $\begin{array}{c}\text { The students who withdrew from the course interrupted } \\
\text { the activities of learning without clarifying specific } \\
\text { doubts concerning the language. }\end{array}$ & $\begin{array}{l}\text { The platform allows you to navigate and perform all } \\
\text { the course activities without being enrolled, and you } \\
\text { can even participate in forums to clarify doubts. }\end{array}$ \\
\hline $\begin{array}{l}\text { Inexperience in the use } \\
\text { of a Virtual Learning } \\
\text { Environment }\end{array}$ & Lack of resources related to the environment. & $\begin{array}{l}\text { The icons created are related to the theme of study, } \\
\text { with the goal of making the location of } \\
\text { resources more intuitive. }\end{array}$ \\
\hline $\begin{array}{l}\text { Lack of sharing } \\
\text { of doubts }\end{array}$ & $\begin{array}{l}\text { The forum to clarify doubts was not used, showing } \\
\text { the preference for external email. The students did } \\
\text { not try to clarify doubts with teachers or obtain } \\
\text { guidelines during the production period/completion } \\
\text { of the proposed activity. }\end{array}$ & $\begin{array}{l}\text { Forum Post, by the teacher, with the most common } \\
\text { doubts put forward in } e \text {-mails. Forum open to any } \\
\text { person who accesses the web site of the course. }\end{array}$ \\
\hline Chat & $\begin{array}{l}\text { There is still the perception on the part of students that } \\
\text { a chat in the environment is not an academic activity. }\end{array}$ & This option was not given. \\
\hline The Course Plan & $\begin{array}{l}\text { The students did not complete the activities as } \\
\text { provided in the plan of the online course } \\
\text { and in official notices. }\end{array}$ & $\begin{array}{l}\text { The students can navigate freely through activities, } \\
\text { and only those requiring certification need to } \\
\text { complete all the activities. }\end{array}$ \\
\hline $\begin{array}{l}\text { Absence of } \\
\text { Dialogism }\end{array}$ & $\begin{array}{l}\text { Dialogue perspective was impaired due to the lack } \\
\text { of involvement of students, despite encouragement } \\
\text { from the teacher. }\end{array}$ & Use of wiki tool. \\
\hline Video lesson & $\begin{array}{l}\text { It was quite brief, which indicates that there is a need } \\
\text { for the production of additional short videos. }\end{array}$ & $\begin{array}{l}\text { The production of three types of video lessons: } \\
\text { presentation of the course; presentation of the contents; } \\
\text { the learning objects for presentation of the content. }\end{array}$ \\
\hline $\begin{array}{l}\text { Use of External } \\
\text { Links }\end{array}$ & $\begin{array}{l}\text { The additional links included in the course, aiming } \\
\text { to clarify possible difficulties, were not accessed. }\end{array}$ & $\begin{array}{l}\text { The links were removed and greater emphasis } \\
\text { was given to the instructional videos. }\end{array}$ \\
\hline
\end{tabular}

the academic environment. As it was anticipated that there could be a problem in relation to navigation in the environment, the private email of the teacher was made available. This feature, therefore, served as a support for students to receive the necessary guidelines. The importance of the e-mail was also evident in comparison to the non-use of the forum of doubts, which remained open during the whole course. The students preferred the e-mail to request clarification. The replacement of the forum with the e-mail originated the hypothesis that there may be a culture installed regarding the underutilization of interactive resources available on the platform due to the habit of on-line communication between teachers and students being made through e-mails. Yet, this raises the question of there being effective digital literacy, both with teachers and students, in order to take advantage of all available resources in the virtual environment. It is also possible to suppose that the students perceive the environment as a formal and controlled space, hence the preference for e-mails, which present greater familiarity on the part of the students.

In relation to the video lesson, it is a legitimate point that a single video was not sufficient to contextualize and present all of the content. Additional videos could be made available with better preparation and technical quality. A further issue to be considered is that, in the virtual environment used, there is no logging in feature for the access of the student, as on the Moodle platform, for example.

Based on the methodology of Van der Maren (2003), which includes the development of the object as well as an application, evaluation, adjustments and new application, from the limits presented by the proposition of the online course in the closed platform of the institution, the new course in an open environment was proposed, on the Moodle platform. The prototype of the course sought to increase the possibilities of the use of digital technology, aiming at academic literacy, from web 2.0 features.

Table 4 demonstrates that the second proposition, related to MOOC, due to being more open and flexible, reduced the possibility of withdrawal, to the extent that the student is encouraged to use the course or even just part of the course or some of the learning objects, according to their objectives, in a perspective of further selfstudy and autonomy. However, in their interactive didactic design, tried to emphasize multidirectional commu- 
nication, with different devices of interaction, but even with the encouragement of mediating teachers, the collaboration was reserved and concentrated on the teacher-student relationship, which is shown in the use of e-mail on the closed course, a resource with which the student is more familiar with, and also implies less exposure when submitting questions. Instead of sharing with everyone, these are only checked by the teacher. The proposition of MOOC also presented a greater variety of content devices in relation to language and format, exploring, especially, the potential of video lessons and using external links with less emphasis.

\section{Discussion of Results}

By the research results, it can be seen that particular care should be taken even before the start of a distance course, in order to prevent possible anticipated dropouts.

Firstly, it is important to choose the time to offer of the course, because in the two proposals, the time and the scenario of presentation were fundamental when motivating the continuity or not on the course. If training is offered at the moment in which students can leverage immediately the result of learning in the academic disciplines, the possibility of continuity on the course and implementation of activities seems to be greater.

Another important factor to determine the participation of students on a distance course can be the understanding of commitment required for such; in general, people forget that the launch of a distance course requires commitment, discipline, auto-didactic skills and, above all, time (Palloff \& Pratt, 2004).

The little familiarity with the virtual environment can also be a limiting element of the success of the student in the completion of the activities, leading to the use of the traditional features of communication, such as e-mail. Some research (Paiva, 2012) presents advantages of e-mail, such as the ease of collaboration and discussion and the creation of discussion communities, in addition to the fact that the user can easily be found, in the case of its use within a proposal for distance training, implemented in a virtual environment that offers other possibilities of a more open sharing, such as the forum. However, the use of e-mail can have the opposite effect, leading the students to not sharing their doubts and not collaborating with colleagues, restricting learning to their exchange with the teacher.

Regarding the necessary autonomy for the participation of distance training, although the course was planned to be self-explanatory, especially before the public of the university, it was necessary to perform effective monitoring, apart from feedback, throughout the activities. This difficulty can be understood from the considerations of Eneau (2008) who affirms that autonomy should be treated in a perspective of educational reciprocity, because, even in the case of adults, the process of empowerment stems from the collaborative relation between the student and another person. Not even before delivering the first version of the summary for correction, was there dialog with the tutor in order to obtain additional guidance or clarification of doubts, making it evident that students require more intensive monitoring on the part of the tutor in the completion of the activities. In addition to the forum, participation in the chat are unpopular with students, who have not understood the activity as academic but, as a mere form of online conversation. Some have not participated simply because they have underestimated the context and the importance of academic activity. Those who attended had good participation, but their placements turned exclusively to the semantic content of the text. There is no doubt that it was a rather provocative text, but it was clear that it did not meet the schema of the strategy of reading as prompted, which indicated a superficial reading of the text. Even when encouraged from the dialogical perspective adopted by the tutor, students did not answer or engage in an effective dialog. Another unpopular tool was the blog, provided for conducting the course evaluation. There was no participation, since the students sent the assessment by e-mail, alleging that they cannot make the entry on the platform. Once again, it raises the hypothesis that there is a culture of limiting the use of the resources of the virtual environment, perhaps secured by teachers in relation to dispensing these features, replacing them with e-mails, so that the students could even ask for help to post the assessment on the blog.

On the other hand, the assessments of the students who took the closed course showed the importance of the dialogical perspective and mediation. They show that there was good acceptance of the course and the way the students answered the discursive question demonstrates that affective motivational aspects that facilitate the learning process were present, as indicated by Feuerstein, Feuerstein and Falik (2014). Even after having terminated the course all tutors received e-mails through the virtual institutional learning environment, from some students requesting clarification of the Portuguese language, because they were writing their final assignment and had some doubts. 
From the two experiments, Table 5 synthesizes the potential found in the two proposals. It is important to emphasize that this potential was categorized for the purposes of this study, but within the environment they are interwoven. Therefore, in the table, they were classified from the strongest sense of their representation.

The differential between the two undertaken propositions is first in the fact that the Moodle platform has shown, in the experiments conducted, as being more customizable than the institutionalized platform in the context of the institution under study. The MOOC proved to be more friendly in relation to the prospect of selflearning and of cooperation between individuals. In addition, more video guidance was performed and, from the demonstration of the importance of mediation, interaction and affectivity in online courses, features such as the forum, chat and e-mail were evident.

\section{Final Considerations}

Education (in this specific context, higher education) requires innovation in products and processes for which there is a significant improvement in the learning process of students. The difficulties in relation to academic literacy, as presented in this research, show this scenario.

The development and integration of digital technology stand out as allies to strengthen the learning of the Portuguese language, in that they allow for the application of distinct instructional strategies that involve the active participation of the student. This is fundamental to facilitate meaningful learning, especially if anchored in concepts such as mediation, interaction and dialog, which are consistent with the prospects of an educational process that is more global, integrating social needs, and is more affective, creative and flexible.

From the two propositions presented, it was possible to identify that the online courses have a real possibility to support the continued training of the university student, provided that the proposals were attentive to the limiting factors and enhancers of resources.

In the first version of the course, we sought to understand and validate how the integration of the various resources to would improve the academic facet of the Portuguese language. We started from an initial plan, with a

Table 5. Potential presented in the two proposals of course.

\begin{tabular}{|c|c|c|}
\hline \multirow{2}{*}{ Category } & \multicolumn{2}{|r|}{ Type of Environment } \\
\hline & Closed Course Environment & MOOC \\
\hline Mediation & $\begin{array}{l}\text { Affective motivational aspects that facilitate } \\
\text { the learning process were identified by students } \\
\text { in relation to the mediation undertaken. }\end{array}$ & $\begin{array}{l}\text { The pedagogical mediation, is usually established between } \\
\text { human mediators (participants) and non-human (technology). } \\
\text { There may eventually be the mediation of the teacher/tutor. }\end{array}$ \\
\hline Interaction & $\begin{array}{l}\text { The students judged the form of interaction } \\
\text { as interesting, as they saw that they could ask } \\
\text { without interruption or without } \\
\text { personal exposure. }\end{array}$ & $\begin{array}{l}\text { The mediation via technology provides a channel permanently } \\
\text { open to trade, interactions, dialogs, constructions, among } \\
\text { students and between them and the tutor. } \\
\text { With the use of the tools and the environment created in MOOC, } \\
\text { all participants had access to each other's writing, } \\
\text { managing to assist with the work of their peers. }\end{array}$ \\
\hline Dialogicity & $\begin{array}{l}\text { The correction by means of reviews on } \\
\text { documents encouraged the dialog and } \\
\text { interaction between student and tutor, } \\
\text { allowing for individualized care. }\end{array}$ & $\begin{array}{c}\text { The Moodle platform allows customization of the total home page of a } \\
\text { discipline and to render it a more familiar and intuitive interface for the } \\
\text { student, which produced a good evaluation in relation to interest. } \\
\text { A variety of short videos were produced, with the purpose of } \\
\text { demonstrating the stages of completion of the final assignment. } \\
\text { The Moodle platform was very well evaluated by participants in } \\
\text { relation to its functionality and organization. } \\
\text { The resources forum, video chat, and wiki were well evaluated } \\
\text { by the participants, who have understood its use and integration } \\
\text { with regards to the purpose of the course. }\end{array}$ \\
\hline Flexibility & & $\begin{array}{l}\text { The videos have the characteristic of flexibility, i.e. they can be } \\
\text { accessed several times, until the student understands the contents. }\end{array}$ \\
\hline Autonomy & & $\begin{array}{l}\text { The MOOC makes use of distinct instructional strategies, which involve } \\
\text { the active participation of the student, which is consistent with the } \\
\text { perspective of interactivity, autonomy, flexibility and creativity. } \\
\text { The MOOC is accessible to anyone who is prepared to study and } \\
\text { learn and is not restricted to a group of people. }\end{array}$ \\
\hline
\end{tabular}


pedagogic proposal and technological resources produced and selected from a theoretical framework on mediation, the teaching of the Portuguese language, adult learning and the possibilities offered by digital resources that are available on the web. Its validation among students of the scientific initiation program generated a new proposal in which it was possible to correct and adapt the resources that, according to the literature, were suited to the online learning process. However, in the experiment that was performed, it was shown to be inadequate or partially appropriate to the conception of the teaching of the Portuguese language and the mediation adopted by the study.

Another limitation of the first proposal was the application of the concept of self-learning. The selected technology and the use of a virtual environment, in which the participation in the course occurred upon registration, were not favored in that students would have to use the resources to study alone. Such a fact pointed to a new application: the use of the concept of MOOC. In this proposal, resources were created by which the students could study alone, performing the tasks and readings, or enroll on the course, if they wished to receive a certificate. Resources were also proposed that might encourage sharing between students by means of different formats of online communication, overcoming the perspective that learning using online platforms involves only a single construction and self-sufficient knowledge. In sum, the MOOCs may offer excellent opportunities for continuous education to students, since they allow the attendance in a wide range of courses and in large centers of academic excellence without costs and thereby meeting their needs.

To analyze the relation with the language of freshmen students and students in higher education, the study was finally able to demonstrate that it would be useful for there to be writing development projects in all disciplines, mediated by digital technology and which are listed in the curriculum, starting in the first semester and extending until the last half of the course. It is essential to emphasize that there are free and open platforms, with good results, which allow for the development of proposals in a democratic perspective of access and the production of knowledge, and of the collective construction of meaningful learning.

\section{Acknowledgements}

We the National Council for Scientific and Technological Development (CNPq) for making this study possible.

\section{References}

Antunes, I. (2003). Portuguese Classes: Meeting and Interaction (8th ed.). São Paulo: Parábola.

Araújo, G. M. L., Careno, M. F., Luna, M. J. M., \& Leal, M. V. (2005). Linguistic Competence of University Students and the Degree of Understanding and Texts Production: The Sociological Dialing. Proceedings of the Annual Meeting da SBPC, Fortaleza, 57.

Bakhtin, M. (2010). Marxism and Philosophy of Language (14th ed.). São Paulo: HUCITEC.

Bardin, L. (2010). Content Analysis. Translation Luís Antero Reto e Augusto Pinheiro. Lisboa: Edições.

Brasil (1997). Ministério da Educação. National Curriculum Guidelines: Portuguese. Brasília: MEC.

Cunha, M. I., Zanchet, B. B. A., \& Ribeiro, G. M. (2013). Undergraduate Teaching Quality: Culture, Values and Selection of Professors. Práxis Educativa, 8, 219-242. http://dialnet.unirioja.es/servlet/articulo?codigo=4383856 http://dx.doi.org/10.5212/PraxEduc.v.8i1.0009

de Dallegrave, J. L. M., \& Vosgerau, D. S. R. (2014). Mediation Process to the Necessary Writing Skills in Academic Context with Digital Media and Technologies. Curitiba: Dissertação (Mestrado)-Pontifícia Universidade Católica do Paraná. http://www.biblioteca.pucpr.br/tede/tde_busca/arquivo.php?codArquivo=2965

Elias, V. M. (2011). Teaching Portuguese Language: Speaking, Writing and Reading. São Paulo: Contexto.

Eneau, J. (2008). From Autonomy to Reciprocity, or Vice Versa? French Personalism's Contribution to a New Perspective on Self-Directed Learning. Adult Education Quarterly. http://aeq.sagepub.com/content/58/3/229.short

Eneau, J., \& Develotte, C. (2012). Working Online Together to Enhance Learner Autonomy. ReCALL, 24, 3-19. https://www.researchgate.net/publication/259418123 Working online together to enhance learner autonomy http://dx.doi.org/10.1017/S0958344011000267

Feuerstein, R., Feuerstein, R. S., \& Falik, L. H. (2014). Beyond Intelligence: Mediated Learning and the Brain Habillity to Change. Petrópolis: Vozes.

Gomez, A. P. (1992). The Practical Thinking Teacher-Training of the Teacher as Reflective Practitioner. In A. Nóvoa (Ed.), The Teachers and Their Training (pp. 95-114). Lisboa: Publicações Dom Quixote, Instituto de Inovação Educacional.

Kenski, V. M. (2003). Technologies, Traditional and Distance Learning. Campinas: Papirus. 
Koch, I. G. V. (2002). The Textual Cohesion. São Paulo: Contexto.

Marcuschi, L. A. (2003). Conversation Analysis. São Paulo: Ática.

Nicola, R. M. S. (2011). Retextualization and Language Concepts in the Formation of the Reader. In Proceedings of the Nacional Education Congress.

Paiva, V. L. M. O. (2012). E-Mail: A New Text Genre. In L. A. Marcuschi, \& A. C. Xavier (Org.), Hypertext and Digital Genres New Forms of Construction of Meaning (3rd ed.). São Paulo: Cortez.

Palloff, R. M., \& Pratt, K. (2004). Virtual Student. Porto Alegre: Artmed.

Santos, E. O., \& Riccio, N. C. R. (2011). Open Courseware Design: An Online Education Experience on Teacher Training in UFBA. In D. M. V. Barros, et al. (Eds.), Education and Technologies: Reflection, Innovation and Practices. Lisboa: Universidade Aberta de Lisboa.

Schneuwly, B., \& Dolz, J. (2011). Oral and Written Genres in School (3rd ed.). Campinas: Mercado das Letras.

Silva, M. (2006). Interactive Classroom (4th ed.). Rio de Janeiro: Quartet.

Travaglia, L. A. (2000). Grammar and Interaction: Proposal for Grammar Teaching in Elementary and High School (5th ed.). São Paulo: Cortez.

Van der Maren, J. M. (2003). Methódes de recherche pour l'education. Montréal: De Boeck Université.

Zabalza, M. A. (2004). University Education: Scenery and Protagonists. Porto Alegre: Artmed.

\section{Submit or recommend next manuscript to SCIRP and we will provide best service for you:}

Accepting pre-submission inquiries through Email, Facebook, LinkedIn, Twitter, etc.

A wide selection of journals (inclusive of 9 subjects, more than 200 journals)

Providing 24-hour high-quality service

User-friendly online submission system

Fair and swift peer-review system

Efficient typesetting and proofreading procedure

Display of the result of downloads and visits, as well as the number of cited articles

Maximum dissemination of your research work

Submit your manuscript at: http://papersubmission.scirp.org/ 